\title{
Author Index Volume 3
}

Owen, Catherine, "The Sleeping Dragon Is Gathering Strength": Causes of Sinophobia in Central Asia

1 (2017) 101-119

Zhang, Chun, The Belt and Road Initiative and Global Governance in Transition

2 (2017) 175-191

Steinbock, Dan, The Great Shift of Globalization: From the Transatlantic Axis towards China and Emerging Asia

2 (2017) 193-226

Kapur, Devesh, The Quest for Global Leadership: U.S.-China Competition in Multilateral Financial Institutions

2 (2017) 243-265

Khodaee, Esfandiar, see Izadi, Foad

2 (2017) 299-323

Izadi, Foad \& Khodaee, Esfandiar, The Iran Factor in U.S.-China Relations: Guarded Engagement vs. Soft Balancing

2 (2017) 299-323

Besada, Hany \& Salam, Justine, China's Energy

Strategy in the MENA Region

4 (2017) 597-619

$\mathrm{Yu}$, Hongyuan, G20 and the Reform of Global Energy Governance

2 (2017) 227-242

Li, Jiacheng, Developing China's Indian Ocean Strategy: Rationale and Prospects

4 (2017) 481-497

Chen, Jiawen, Why Economic Sanctions on North Korea Fail to Work?

4 (2017) 513-534

Yang, Jiemian, Bridging the Conceptual Gaps: New Imperatives for Managing China-U.S. Relations

1 (2017) 19-38

Yang, Jiemian, Managing China-U.S. Relations in the

Trump Era: Approaches and Policies

3 (2017) 357-375

Long, Jing, China's Engagement in the Danube

Sub-Region: Opportunities and Challenges

4 (2017) 535-550

(c) 2017 World Century Publishing Corporation and Shanghai Institutes for International Studies China Quarterly of International Strategic Studies, Vol. 3, No. 4, 621-623

DOI: 10.1142/S2377740017990019 
Chen, Julie Yu-Wen \& Jiménez-Tovar, Soledad, China in Central Asia: Local Perceptions from Future Elites

Salam, Justine, see Besada, Hany

3 (2017) 429-445

Brown, Kerry, China's Foreign Policy Since 2012: A

Question of Communication and Clarity

4 (2017) 597-619

3 (2017) 325-339

Jin, Liangxiang, China's Role in the Middle East:

Current Debates and Future Trends

1 (2017) 39-55

Mayer, Maximilian \& Peters, Susanne, Shift of the EU Energy Policy and China's Strategic Opportunity

1 (2017) 137-158

Baz Khetran, Mir Sher \& Anjum Saeed, Muhammad, The CPEC and China-Pakistan Relations: A Case Study on Balochistan

3 (2017) 447-461

Anjum Saeed, Muhammad, see Baz Khetran, Mir Sher

3 (2017) 447-461

Shangwe, Muhidin, J., China's Soft Power in Tanzania: Opportunities and Challenges

1 (2017) 79-100

Antonopoulos, Paul, The Kangaroo, the Bear, and the Dragon: Australia-Russia-China Relations in the "Asian Century"

3 (2017) 411-428

Cai, Penghong, The South China Sea: Troubled Waters in China-U.S. Relations

2 (2017) 283-298

Asante, Richard, China's Security and Economic

Engagement in West Africa: Constructive or

Destructive?

4 (2017) 575-596

Muhammad, Saeed, From the Asia-Pacific to the Indo-Pacific: Expanding Sino-U.S. Strategic

Competition

4 (2017) 499-512

Yilmaz, Serafettin, Exploring China's Arctic Strategy:

Opportunities and Challenges

1 (2017) 57-78

Wang, Shichen, Sino-Swiss Strategic Partnership: A

Model for China-Europe Relations

2 (2017) 267-282

Jiménez-Tovar, Soledad, see Chen, Julie Yu-Wen

3 (2017) 429-445

Peters, Susanne, see Mayer, Maximilian

1 (2017) 137-158

Yakunin, Vladimir, The Future of World Order:

Building a Community of Common Destiny

2 (2017) 159-173 
Xing, Wei, Lancang-Mekong River Cooperation and

Trans-Boundary Water Governance: A Chinese

Perspective

3 (2017) 377-393

Vogt, William J., China and Lusophonia: A Compatible Alliance Network?

4 (2017) 551-573

Yang, Xiaoping, Managing Leadership in the Indo-Pacific: The United States' South Asia Strategy Revisited

4 (2017) 463-480

He, Yafei, China's New Role in Global Governance:

Shaping the Emerging World Order

3 (2017) 341-355

Zhou, Yiqi, China's Partnership Network Versus the U.S.

Alliance System: Coexistence or Conflict?

1 (2017) 1-18

Chen, Youjun, The Emerging U.S.-Japan Energy

Alliance and Its Implications for China

1 (2017) 121-136

Wang, Yuzhu, Globalization Revisited: Institutional

Constraints and Ways Forward

3 (2017) 395-409 